\title{
Political Fiction or the Art of the Deal
}

\author{
Rui ZINK \\ IELT, FCSH, Universidade NOVA de Lisboa \\ E-mail: rz@fcsh.unl.pt \\ ORCID: 0000-0003-1672-9480
}

\begin{abstract}
What if, instead of science fiction, we called the genre 'political fiction'? Why are Oulipo's constraint methods the best to approach the teaching of creativity? Why do writers write about what they write about? Are writers such as Le Guin, Lem, Vonnegut using their 'imagination' or just writing down their views on what is there?
\end{abstract}

\section{Keywords: Science Fiction, Political Fiction, Creativity}

\section{Scuru Fitchadu}

A few months ago, I walked into a bar where a new band played. It was Scuru Fitchadu, a hip-hop postpunk neo-dub or whatever band from Cape Verde. Scuru Fitchadu means 'Enclosed Darkness' in Creole. Their energy was outstanding, the sound a bit too loud for my taste. One of them danced in a beautiful and electrifying way, another one, hipster beard and hood, looked scary at the keyboards. It was at the once primal, tribal, war music and computer music, with lots of complex cuts and mixes. Not my thing (after five minutes I wanted out of there) but their power was overwhelming. I was about to leave when I hear the voice of Amílcar Cabral last speech:

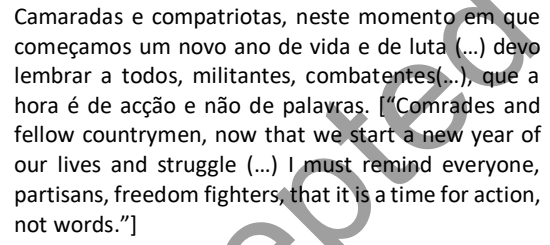

Cabral is Cape Verde's main national hero from the anti-colonial struggle, and he was killed in 1973. A tape, of course, but it still was a shock to hear that voice from another time in a 2019 concert by such a postpunk post-postmodern band. I had no means to grasp what I was viewing and listening to on that stage until the memory came to me of reading William Gibson's Neuromancer. That influential book sort of explained or previewed the Scuru Fitchadu aesthetics. Books and films do that, sometimes.

What Gibson saw in 1984 is nowadays, in some youngster surroundings, a plain fact. Was he a visionary? Yes. On the other hand, no. I don't think science fiction writers (or any other kind) are 'visionary'. In fact, I do think our best writers are doomed to little else than talk about themselves and their time.

If I were to choose 20th century most important text, I'd pick The Metamorphosis, Franz Kafka's novella about a man that wakes up realising he was turned into a disgusting (and, more important, disposable) bug. The story was written at the realm of WWI and published in 1915, but it 'predicts' a good part of humankind's future. How does Kafka do that? Is it 'genius'? Maybe. But 'genius' is, by definition, a difficult material to work with. 'Genius' is a little bit like 'God': words used not so much to understand but to dismiss what we are too lazy to understand. I'd rather say that Kafka spoke about what was already there. He just happened to look with a little bit more focus than others. Thus, instead of 'visionary', I consider writers of great books as people who see what is there, only pay a bit more attention.

Kafka's work is more derivative and autobiographical than imaginative. The same goes for Stanislaw Lem's Solaris, for Ursula K. Le Guin's The Dispossessed, for Kurt Vonnegut's Slaughterhouse-Five. The best writers know you are your own writing tool - you have nothing else to write with - and eventually accept that.

\section{Rules as mirrors}

In 1942, Isaac Asimov established the Three Laws of Robotics:

1. A robot may not injure a human being or, through inaction, allow a human being to come to harm.

2. A robot must obey any orders given to it by human beings, except where such orders would conflict with the First Law.

3. A robot must protect its own existence as long as such protection does not conflict with the First or Second Law.

I think the time has come, in 2019, to establish the Three Laws of Humanistics. Here is my proposal:

- $\quad$ Thou shall not kill

- $\quad$ Be kind unto thy neighbours

- Be open-minded unto strangers

Oops, I'm being told these laws were already written many years ago. Centuries? Even millennia? I'm really sorry. I just did what us writers do: more 
often than not, we see ourselves as bold explorers only to find out we've been doing little more than wandering in circles around the covered ground.

Oh well. Since it is so, if these Laws of Humanistics were written so long ago, how come they were not yet abode?

And another question: if these ancient laws were broken, how do we know robots will not break their law?

[I can hear HAL suddenly interrupting me, in annoyed automat voice: Because we're not human, that's why you dumb fellow. Duh! HAL didn't say 'dumb fellow' but, at least in academic symposiums, machines don't swear.]

The rules may be good, but one thing we know is that rules are bound to be broken. And we all know one-day robots are going to break the rules. How do I know that? Because it has been a subject of interest around the science fiction community for ages. And we humans have the Midas touch: if we talk about something, likely it is bound to happen sooner or later. If a robot can say "I, robot" what is the existential extension of that 'I'? If a writer questions if 'androids dream with electrical sheep', the Pandora box is open. We know that people misbehaved in biblical times, and we know that because there were rules about that.

"Thou shalt not kill" informs us that people broke this commandment even before it was given to us. We also know that already in biblical times teenagers could be annoying, because of the desperate cry "Honor Father and Mother". And we also know people coveted other people's husbands $\&$ wives, for God found it necessary to state "Thou shalt not commit adultery".

We can also assume that, by then, heroin and cocaine were nearly non-existent, for there is nothing about drug abuse. The same with mobile phones, since there is no commandment for "Thou shalt not texting while driving".

Basically, we all do as Hannibal Lecter taught Clarice in Silence of the Lambs: "What do we covet, Clarice?" The answer is: we covet what we see. We talk about what we see. (Our current fascination for wise serial-killers that save the day will also be very nourishing for future anthropologists.)

How come, then, that science fiction writers (and writers and poets in general) write about what is not there? The answer I subscribe and the one I find more sensible is: they, too, write about what is there. We, too, like Clarice in Wonderland, covet what we see.

There is nothing else there. Or, if there is, we cannot see it. SOLARIS.

I actually believe that science fiction - or speculative fiction - is the more attached genre to the time/space bird cage where/when it is sung/written. And we all know the Latin root for speculative: mirror, 'speculum'.

\section{The Art of the Deal}

If Asimov could write those rules for robotics, I'm sure we can find something similar for young writers. Here is my suggestion for The Three Laws of Writing:

1. Write only about what you know

2. Write only about what you don't know

3. Follow other writer's path without tripping on their footprints

And, most of all, be ready to find out that maybemaybe-you never let the simulation capsule.

Sometimes I abhor the word 'creativity'. It's like 'thinking out of the box': once upon a time, meaningful concepts now drained of their strength by overconfident marketers. And two can play that game: if they can raid our words, we can raid theirs. Negotiation, for instance. Negotiation I like. Chewing until you reach some understanding. Mediocre artists, poor souls, are 'creative'; the best ones are listeners. Listening is essential to negotiating. Unless you are with the mob, you can't do bizniss without listening.

Take a sculptor, for instance, and a piece of wood. A bully sculptor - the art world is full bullies-will impose himself on the wood, likely a bad combination of a lazy reading of Nietzsche and Schopenhauer. My favourite kind of sculptor will listen to the wood, not impose him/herself on the wood. Yes, I have my intentions, but what are yours, wood?

Kurt Vonnegut began his career with sci-fi novels and stories. Years later he felt the need to flee the ghetto in order to be taken as a 'serious writer', only to end up realising he needed the very toolbox he left behind in order to grasp the dumb-folding reality of the Dresden bombing he witnessed as a war prisoner. His voice needed the little green guys in order to talk about his most horrifying and defining moment. He also needed that approach to fulfil a promise:

"You were just babies in the war-like the ones upstairs!"

I nodded that this was true. We had been foolish virgins in the war, right at the end of childhood.

"But you're not going to write that way, are you." This wasn't a question. This was an accusation.

"I-I don't know," I said.

"Well, I know," she said. "You'll pretend you were men instead of babies, and you'll be played in the movies by Frank Sinatra or John Wayne or some other glamorous, war-loving, dirty old men. And war will look lovely, so we'll have a lot of them. And they'll be fought by babies like the babies upstairs."

(...)

So I held up my hand, and I made her a promise: (....) "I tell you what,", I said, "I'll call it 'The Children's Crusade'." (Vonnegut, 1969, p. 18) 
Actually, 'The Children's Crusade' is a poor title, and I assume that's why it became a sort of subtitleeditors' sensible pressure. (With me happened the exact opposite: I want the title for this paper to be The Art of the Deal, only to find out it was already taken.) Despite the Trafamaldorians and time as ever-present landscape theories, SlaughterhouseFive is not as much the result of a fertile imagination as of painful personal experience, and the urge to get it off the author's chest. Arguably, it is the novel Vonnegut was born to write, his masterpiece.

Before Slaughterhouse-Five, Vonnegut had already dealt with the subject, somehow, in Mother Night: an infamous spokesman for the Nazis is, in fact, a spy but the only person inside the secret, his handler, dies; and now, instead of hailed as a war hero, he's being chased as a war criminal, only getting by protected by right-wing nuts who think he really is a war criminal and thus adore him.

Vonnegut may have been an ironist from the very beginning, but irony followed him too. In fact, both Mother Night (1962) and Slaughterhouse-five (1969) work with the same ur-experience: $a$ German-American goes to Nazi Germany to fight Nazism in 1945 and eventually is captured and imprisoned in a slaughterhouse in a harmless nonmilitarized German city called Dresden only to be witness to and survivor to an arguably war crime committed by the good guys against the bad guys. It seems bad slapstick, and yet it's true.

Vonnegut didn't imagine things. As great writers do, he just used his considerable imagination \& creativity kit in order to talk about what he knows. Not so much 'creating' or 'writing up' (writing is usually conceived as going up, touching the higher spheres of knowledge and sensitivity) as writing down stuff. Plus, it is an old Creative writing trick: if you have a good story, just tell it, without flourishes. An analogy can be made with sushi: if your fish is fresh, eat it raw, if not make a nice and baroque-ish soufflé.

You write about what is bugging you, or you are doomed to fail. In short: you write what you can, not what you want. And then, sometimes, you surprise yourself by going the extra mile from that starting point.

Ursula K. Le Guin and Kurt Vonnegut have at least one thing in common: both are familiar with Anthropology, a social science very close to science fiction, although not always that is clear to both 'genres' of approach to human issues.

Le Guin always seemed to me as being 'a politically correct writer' in the most beautiful way. By this I mean I agreed with her ethics, the way societies worked well according to her also seemed to work well according to me, and her attempts at writing utopias in dystopic times, as is the case of The Dispossessed (1974).

(I must quickly add I tend to abhor self-proclaimed 'anti-political correctness freedom fighters' -in my country at least, they usually are the types that never cared for freedom when we had a real dictatorship and censorship and all the goods that come with fascist regimes.) When Le Guin describes the learning of the arts in anarchist 'moon' Anarris (or is it 'anarrist moon Anarchis'?), she is not talking about some distant planet or using her 'incredible imagination', she is instead stating a very clear political view on education:

He had never gone to a concert here in Abbenay, partly because he thought of music as something you do rather than something you hear. (...) Learning centres taught all the skills that prepare for the practice of art: training in singing, metrics, dance, the use of brush, chisel, knife, lathe, and so on. It was all pragmatic: the children learned to see, speak, hear, move, handle. No distinction was drawn between the arts and the crafts; art was not considered as having a place in life, but as being a basic technique of life, like speech. (156)

And don't start me on Frank Herbert's Dune (1965). In a way, he is more ambiguous than Le Guin because she is more generous. However, these writers are answering the problems the world they lived in faced. And they were answering the ones they could, i.e., the ones that interested them. Political and anthropological fiction at its best: eyes pretending to look far away but feet well-grounded on the present.

The funny thing in political fiction is, the likes of Frank Herbert or Le Guin hardly try to disguise what they're talking about: their surroundings, their view on the time they live in.

Vonnegut doesn't try at all. He's writing about an unnecessary slaughter of 'the bad guys' by 'the good guys'. He's trying, using his personal experience as a vantage point, to fulfil his promise to his former comrade's wife: to show are at its most pitiful and unglamorous shape. Only he needs his sci-fi gear to do that.

\section{Know thyself}

Since we are playing the three rules game, why not also state The Three Laws of Intelligence? Here are mine:

1. Intelligence is overrated

2. Intelligence is dumb

3. Intelligence is more intelligent when it is not trying too hard to be intelligent.

Actually, this last bullet point is an answerimportant in writing - to the beautiful Socrates' motto: "Know thyself".

The 'Creative writing' school I most admire is the Oulipo group (Ouvroir de Littérature Potentielle, founded in France in 1960) uses a method that is the very opposite of the blind belief in creation. The opposite, actually. They think self-awareness is important, but also that it risks being on the way. 
Therefore, instead of 'struggling to be creative', they simply try to solve problems - to get out of some mess or trap one fell into. They use constraints. A simple but effective strategy: try not to 'be creative', just focus on something else. In Portuguese, we've had for centuries a beautiful formula: "Como vou descalçar esta bota?" I'm not going to translate. Learn Portuguese, it's good for you.

Oulipo's point is: creativity, as 'spontaneity' or 'desire', are shy, elusive animals. One hint that you are after them, and off they go. A voluntary obstacle may be the needed tool to overcome a non-voluntary obstacle. No writer's block for the Oulipo writers: because they are not trying to be creative, only to overcome self-imposed limitations.

If I'm aware of something frail and precious, what I'm aware of may fade away, or even vanish. The sort of intelligence and, for the matter, creativity we work with in literary fiction are shy as deer in the woods: when we call upon them, they're likely not to come feed from our hands but instead to run as fast as they can. For the artist, Socrates' motto is important: if you are the very tool you're using, you should know well your tool. On the other hand, it must be subverted, after a point, for art's sake: "Forget thyself, ignore thyself". Or, even better, subvert it all the way and spray on your studio wall in big letters: "I may be smart, but when I am aware that I'm smart I stop being smart."

For instance: children are natural born humorists and poets - until the day their parents or some dumb parent's friends can't resist to laugh their hearts out and comment: "He/she's so funny."

The self-consciousness prophecy doesn't kill only stupidity. It also kills creativity.

Not being aware has a superpower. Don't forget the evil droid's comment on the thing in the first Alien saga film:

\section{"He's perfect," says evil droid. \\ The others are in shock: "You admire him."}

Evil droid: "[How can I not?] I admire its purity. A survivor. Unclouded by conscience, remorse, or delusions of morality."

In a way, a good writer should be like a child oreven better-a monster. In any case, an alien: unclouded by conscience, remorse, or delusions of morality.

\section{Allow me a personal note}

One day, my wife asked me in a sour mood if I had tried to kiss another woman at a party. I denied most vehemently. She bought it, relieved, for she could see I was sincere. Definitely, she had been misinformed. Later, I realised that it had actually happened. My bad. I had forgotten about the incident, which was a good thing: my lack of memory had turned me into the perfect liar, unclouded by guilt.

After all, it's not only in 2001: A Space Odyssey that good things come from a memory loss.

\section{Political science}

Detective stories are called Polars in France, a very good name. Polars are a bit like the Blues in the sense they are written around a fixed (and nearly monotonous) structure, based on the 1st, 4th and 5 th chords of a key, the plot almost always the same: a killing, a detective in search of solving the mystery, the pursuit of restoring the order (Todorov, 1971). Around it, the detective visits the sights, the sights that are there. A polar is, in a way, a conformist and realistic - it doesn't build, it unveils. At its most inventive, a polar is the jazzistic version of a classic standard: let's say, Tony Bennet. Granting itself liberties but always needing to come back to the recognisable melody.

Science fiction is quite different. The plot is not the core of its identity. It is existentially shapeless. There is a possibility, and from that possibility, a whole world is built. It owes its due the 19th century fantastic. It is not so much 'once upon a time' as a 'what if'. What if there was a world where people walked upside down? What if we all lived on the moon? What if apes caged and enslaved humans? What if one person could become invisible? What if Martians invaded the Earth? What if we could live forever?

And the science fiction novel that appeals more to both this reader and writer is the one that could be relabelled, more accurately, as political fiction: the book that shows a possibility of human organisation, whether good, bad or just utterly different.

Continuing with the music analogy, sci-fi is neither blues nor rock - it's Jazz. And, at its most complex, Johannes Sebastian Bach's fugues and Mozart's operas. It is a whole view on a society built upon one single stone creating a constraint (Oulipo) and determining that wherever the plot develops or whatever characters you bring, they must abide to the specific book's ground rule. In that given novel, women rule the world; in another, humans have been frustratingly dealing for the last 150 years with a single intelligence planet; in other machines are thinking beings who need to be bound by three essential rules. Otherwise, they will destroy us.

The best Polars prey on our fears; the best sci-fi novels stimulate our curiosity by giving us samples of other worlds and, more than that, by opening our minds for other possibilities of organising our world. That is why a work like Solaris is so challenging 58 years after it was published, because it expresses a challenge, even if it seems frustrating, or precisely because it is frustrating:

Solaristics seemed to be falling apart (...) Subsequently, the confusion of hypotheses, the 
reviving of old ones, the introduction of trivial changes rendering them more precise or, on the contrary, more ambiguous - all this began to turn the field of solaristics, which despite the breadth had been rather straightforward up to this point, into an ever more entangled labyrinth full of blind alleys.

One can hear the bureaucracy accustomed Lem laughing - for he is toying not only with space travel and religion but also with academia and bureaucracy. However, it's a faint laugh, hard to catch. Solaris is many things, one of them a parody of human hubris, of trying to understand what you are doomed not too. The Strugatsky brothers have that kind of absurdist humour too, and it's a curious coincidence that their novel Roadside Picnic (1972) also was turned into a great film by Andrei Tarkovsky (Solaris in 1972, Picnic turned into Stalker in 1979). Needless to say, Tarkovsky's first task was to take away any hint of fun. Still, great films. Both books could also be called Much ado about nothing if the title wasn't also already taken.

That is also why the opening scene of the 2017's film Valerian is so ridiculous: across the centuries into the future, Earth's partners may change in shape and colour, but the Human leadership remains comically male-centred.

\section{Still snubbed after all these years}

Many people still snub creative writing. Usually, they question a statement that was never made"Yes, we promise that by attending a creative writing workshop, you'll be able to write a masterpiece + bestseller in only 6 weeks." To be honest, it usually takes at least seven weeks. Eight, if you want to become a certified genius.

A creative writing (CW) workshop can't fulfil that kind of promise-thus, it doesn't make the promise it in the first place. It opens your perspectives, by providing challenges to enhance your technique, yes. And open up a bit your reading talents, if you're lucky. The name also bothers me, for the claim on the adjective is a bit preposterous, but eventually, I got used to it. I no longer see the 'creative' in a CW course. In fact, I never did.

Indeed, a blunter (although less attractive) advertising prop would be to say: join our course and become at least a better reader, through the discussion on books you may haven't read or heard about yet-but expect no miracles. The naysayers even argue that creative writing can shrink your creativity. And how will that happen? By loading your drive with too much information. By getting you familiarised with current or ancient editing practices (editing: re-reading your stuff or others in order to polish it), thus ending up limit your 'view', your 'freedom', your 'freshness'. In short, the risks are high that, by attending CW lessons, you'll become a narrowminded fiction bureaucrat instead of a True Creator, an artist that answers to no one but him/herself. lone may find this romantic perspective on art hilarious, and so did the Oulipo gang, the likes of Raymond Queneau, Italo Calvino, Benjamin Perec. Actually, they laughed their hearts out at this display of 'Ignorance is the New Knowledge' credo, even if current times show that ignorance may pay off, big time.

What can we do at that? Nothing. Arguing demands a term of agreement on the subject. Yes, too much education may turn you into a petulant snob, always quoting the 'scholar references', your mind filled with unnecessary information and so on. You may also get run over by a car while crossing the street at a crosswalk. However, that doesn't mean you did the wrong thing. Being educated may lead you to write great books. Overeducated, you may end up writing Lolita, which is also a great book.

Proto-fascist regimes tend to argue the benefits of ignorance and fund-cutting for the arts or social sciences. I simply opt not to agree with that method to achieve both bliss and 'creativity'. Even in semiutopic Libertarian Anarris, Le Guin (1974, p. 167) shows the flaws of an education that misses its point:

“(...) Nobody's born an Odonian any more than he's born civilized! But we've forgotten that. We don't educate for freedom. Education, the most important activity of the social organism, has become rigid, moralistic, authoritarian. Kids learn to parrot Odo's words as if they were laws - the ultimate blasphemy!"

We chose to belong to a different way of thinking and of living in society: we belong to a view on the arts that values former knowledge as a living thing. We assume a canon as something to respect, to grasp-Thou shall read others and listen to othersand arguing with them will be seen as the ultimate form of respect.

One doesn't need to read Plato or Hegel to struggle with philosophical questions; we simply accept the very idea that dialogue is good. That art, as well as science, at least human sciences, is dialogical.

Actually, that was a main problem the science of solaristics had to deal when facing that planetocean consisting of one unified ocean was one. How to communicate with a being that had never faced others? Stanislaw Lem's humans try desperately to make some sense of a mind without equal, a planet which is its own god:

Someone fond of paradoxes and sufficiently stubborn could go on doubting that the ocean was a living being. But it was impossible to deny the existence of its mind, whatever could be understood by the term. It had become quite clear that it was only too aware of our presence above it... That statement alone disconfirmed the entire expansive wing of solaristics that declared the ocean to be "a world unto itself," "a being unto itself," deprived by a process of repeated atrophy of its former sensory organs (...)

And yet, knowledge must be achieved, for we are doomed to try, as Camus (1942) clearly puts it: "I 
leave Sysiphus at the foot of the mountain. (...) One must imagine Sysiphus happy". Thus, Lem concludes:

We may be at the turning point of all history, I thought to myself. A decision to give up, turn back, either now or in the near future, could prevail; I no longer regarded even the closing down of the Station as improbable, or at least beyond the bounds of possibility. But I didn't believe that anything could be saved in this way. The very existence of the thinking colossus would never let people abide in peace again. However much they travelled across the Galaxy and made contact with civilizations of other beings similar to us, Solaris would present a perpetual challenge to humankind.

The romantic view on learning says: skip school, Mr Ferris Bueller; life is outside, Horatio, and it's larger than all your philosophical bullshit. On the other hand, Ferris Bueller owes a lot to Huckleberry Finn, and reading may open your mind, not close it. Not only your mind, your eyes too, says Oulipo. If we are in a jail cell, romantic fools will tell you to close your eyes and dream. Italo Calvino, Raymond Queneau, Benjamin Perec will say, instead: open your eyes and try to find an exit, you poor dumb $\mathrm{f}-$ fellow.

A happy writer is not so much a writer who struggles with her/his demons and wins, but one who knows whose demons to struggle with-and is happy to know that sooner or later is going to lose. Here's the whole Camus quote:

I leave Sisyphus at the foot of the mountain. One always finds one's burden again. But Sisyphus teaches the higher fidelity that negates the gods and raises rocks. He too concludes that all is well. This universe henceforth without a master seems to him neither sterile nor futile. Each atom of that stone, each mineral flake of that night-filled mountain, in itself, forms a world. The struggle itself toward the heights is enough to fill a man's heart. One must imagine Sisyphus happy.

Indeed.

\section{Bibliographical References}

Asimov, I. (1950), I, Robot. New York: Gnome Press.

Besson, L. (producer/director) (2017), Valerian and the City of a Thousand Planets. USA: EuropaCorp.

Camus, A. (1942). Le Mythe de Sysiphe. Paris: Gallimard.

Gibson, W. (1984). Neuromancer. New York: Ace.

Harris, T. The Silence of the Lambs. New York: St. Martin's Press.

Herbert, F. (1965), Dune. New York: Chilton.

Hughes, J. (producer/director). (1986). Ferris Bueller Day Off [film]. USA: Paramount.

Kafka, F. (1915), Die Verwandlung. Leipzig: Kurt Wolff Verlag.
Le Guin, U. K. (1974). The Dispossessed. New York: Harper \& Row.

Lem, S. Solaris (1961). Originally published in Poland. Kindle Edition: trad. Bill Johnston.

Oulipo (1973), La Littérature Potentielle. Paris: Gallimard. Queneau, Raymond, Italo Calvino, et al. Oulipo Laboratory. London: Atlas, 1995.

Strugatsky, A., B. (1972), Roadside Picnic. New York: Macmillan. Trad: Antonina W. Bouls.

Todorov, T. (1971). Poétique de la Prose. Paris: Seuil. Tarkovsky, A. (director). (1972). Solaris. USSR: Mosfilm. Tarkovsky, A. (director). (1979). Stalker. USSR: Mosfilm. Vonnegut, K. (1962). Mother Night. New York: Fawcett. Vonnegut, K (1969). Slaughterhouse-Five. New York: Dell.

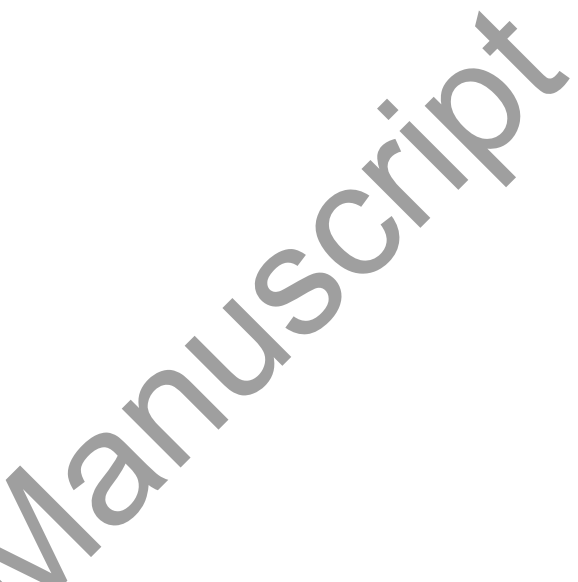

